\title{
Assessment of the impact of the timing of first feeding with live and formulated feeds on the survival and growth of larvae Atlantic sturgeon (Acipenser oxyrinchus Mitchill) in recirculating systems
}

\author{
Iwona Piotrowska, Bożena Szczepkowska, Mirosław Szczepkowski, Michał Kozłowski
}

Received - 25 September 2017/Accepted - 06 June 2018. Published online: 30 June 2018; (Inland Fisheries Institute in Olsztyn, Poland Citation: Piotrowska I., Szczepkowska B., Szczepkowski M., Kozłowski M. 2018 - Assessment of the impact of the timing of first feeding with live and formulated feeds on the survival and growth of larvae Atlantic sturgeon (Acipenser oxyrinchus Mitchill) in recirculating systems - Fish. Aquat. Life 26: 111-120

\begin{abstract}
The aim of the study was to determine the optimum timing of the first feeding of live and formulated feeds and its impact on the survival and growth of larval Atlantic sturgeon, Acipenser oxyrinchus Mitchill, reared in recirculating systems. The first experiment compared the rearing effects on larvae that were provided live feed (Artemia sp.) at first feeding on 6, 9, and 12 days post hatch (DPH). The timing of the first feeding with live feed had an impact on the specific growth rate, the final body weight, and the coefficient of body weight variation. The most advantageous rearing parameter values were noted in the group given their first feeding $9 \mathrm{DPH}(\mathrm{P}<$ 0.05). The second experiment compared the results of rearing larvae that were first given formulated feed on days 20, 25, and 30 post hatch. The highest specific growth rate and final body weight were obtained by the group of fish given their first feeding of formulated feed on day 20 post hatch $(\mathrm{P}<0.05)$. The timing of the first feeding did not impact fish survival, which was above $76 \%(\mathrm{P}>0.05)$ in all groups. The results of the experiment indicate that the optimum timing of Atlantic sturgeon first feeding on live feed was nine DPH, and on formulated feed it was $20 \mathrm{DPH}$.
\end{abstract}

Keywords: Atlantic sturgeon, Acipenser oxyrinchus, Artemia sp., feeding, larvae, recirculating system

\footnotetext{
Iwona Piotrowska [ [”], Bożena Szczepkowska, Mirosław

Szczepkowski, Michał Kozłowski

Department of Sturgeon Fish Breeding in Pieczarki

Inland Fisheries Institute in Olsztyn, Poland

11-610 Pozezdrze
}

\section{Introduction}

The sturgeons comprise one of the oldest families of fish in the world (Kolman et al. 2008). Overfishing and the immense impact of human activity on the natural environment have led to as much as $85 \%$ of the natural populations of these fish being at risk of extinction (IUCN 2010). One of the affected species is the Atlantic sturgeon, Acipenser oxyrinchus Mitchill, which is being restored to the Baltic Sea area (Kolman et al. 2011). Currently, sturgeon culture is a dynamically developing branch of aquaculture that facilitates the production of caviar, meat, and stocking material (Bronzi et al. 2011). One of the most difficult stages of sturgeon culture is the larval period, when high mortality is observed in some species (Bardi et al. 1998, Gisbert et al. 2000). This can stem from, inter alia, inappropriate water temperatures, egg and larva sizes, yolk sac resorption, and the initiation of larval feeding (Gisbert and Williot 1997, Gisbert et al. 2000, Hardy and Litvak 2004, Ghelichi et al. 2010, Boucher et al. 2014). A particular problem is encountered with Atlantic sturgeon in the initial feeding period which often leads to massive losses (Mohler et al. 2000, Kolman et al. 2011, Szczepkowski et al. 2011). 
Potential causes of this phenomenon include inappropriate larval feeding procedures. Optimizing rearing techniques, including determining the appropriate timing of first feeding can have a significant impact on the growth of and survival of this demanding species. According to Gisbert and Wiliot (1997), initiating feeding too early or too late does not produce any tangible benefits in the form of increased larval growth increments. A review of the available literature on larval behavior of and digestive system development in sturgeon species permits estimating the appropriate timing of first feeding (Gawlicka et al. 1995, Żółtowska et al. 1999, Gisbert and Ruban 2003, Kamali et al. 2006, Kolman 2006, Sanz et al. 2011). This is based on observations of larval behavior, including how the fish swim and school, the resorption of the yolk sac, or the moment the melanin plug is expelled (Gilbert et al. 1999, 2000, Szczepkowski et al. 2000). The aim of the study was to determine the optimum timing of initiating first feeding with live and formulated feeds and its impact on the survival and growth of larvae $A$. oxyrinchus reared in recirculating systems.

\section{Materials and methods}

\section{Study site and origin of study material}

The experiments were conducted at the Department of Sturgeon Fish Breeding (DSFB) in Pieczarki, Inland Fisheries Institute in Olsztyn. The study material originated from the wild Atlantic sturgeon population inhabiting the St. John River (Canada). Following artificial reproduction, the fertilized eggs were transported to the DSFB and incubated in McDonald jars. The study was conducted in two stages during which the optimum timing of the initiation of first feeding with live (experiment I) and formulated (experiment II) feeds were determined.

\section{Experiment I - timing of first feeding of live} feed

On the second day post hatch (2 DPH) 1,800 randomly selected larval Atlantic sturgeon were stocked into nine tanks with a working volume of $0.05 \mathrm{~m}^{3}$ each in a recirculating system. The initial stocking density of each group was 200 individuals with a mean body weight of $0.007 \pm 0.001 \mathrm{~g}$ and body length of $1.1 \pm 0.1 \mathrm{~cm}$.

The duration of experiment I was 14 days. The fish were fed exclusively with freshly hatched Artemia sp. nauplii (Coppens Internationale, Holland) twice daily using a pipette with a volume of 10 $\mathrm{ml}$. The daily live feed ration was $10 \%$ of the fish biomass calculated from cyst dry weight. The first feeding of the larvae in the different groups was on 6 (group T6), 9 (group T9) and 12 DPH (group T12). Each of the experimental variants were conducted in three replicates. Every morning unconsumed feed and dead individuals were cleared from the tanks. Larval behavior was observed to determine the moment the melanin plug was expelled and first feeding began.

\section{Experiment II - timing of first feeding of formulated feed}

The second experiment ran for four weeks. The study material was initially reared Atlantic sturgeon larvae aged 20 DPH with a mean body weight of $0.048 \pm$ $0.001 \mathrm{~g}$ and body length of $2.1 \pm 0.1 \mathrm{~cm}$. The fish were reared in nine tanks in a recirculating system with a working volume of $0.05 \mathrm{~m}^{3}$, and the stock in each comprised 200 individuals. Three experimental groups were created in which formulated feed was introduced on 20 DPH (group F20), 25 DPH (group F25), and 30 DPH (group F30), respectively. Each experimental variant was conducted in three replicates.

The larvae were reared using the commercially formulated feed Perla Larva Proactive 6.0 with a granule size of $0.1-0.3 \mathrm{~mm}$, consisting of $62 \%$ protein and $11 \%$ lipids (Spa Hendrix, Italy). 
Additionally, each of the groups received freshly hatched Artemia sp. nauplii (Coppens Internationale, Holland). For the first two days of feeding, the feed ration was $6 \%$ of the fish biomass, then it was increased to $10 \%$ of the fish biomass. The daily ration of live feed calculated as cyst dry weight was $10 \%$, and this was reduced to $5 \%$ of the fish biomass in the second week of the experiment. In the last week of the experiment only formulated feed was given. Both live and formulated feeds were delivered four times daily. Every day unconsumed feed and dead individuals were cleared from the tanks.

\section{Physicochemical parameters}

During the experiment, physicochemical parameters were measured in outflow water. The oxygen content did not decrease below $10 \mathrm{mg} \mathrm{O}_{2} \mathrm{dm}^{-1}$, and water $\mathrm{pH}$ was in the range of 6.9-7.1 (CyberScan 5500 meter, Eutech Instruments, USA). The average water temperature in experiment I was $20.7 \pm 1.4^{\circ} \mathrm{C}$, and in experiment II it was $22.0 \pm 0.4^{\circ} \mathrm{C}$. The content of total ammonia nitrogen (TAN) was determined with direct nesslerization and nitrite $\mathrm{N}-\mathrm{NO}_{2}$ was determined with sulfanil method (Hermanowicz et al. 1999) using a Carl Zeiss 11 spectrophotometer (Carl Zeiss Jena, Germany). The maximum ammonia nitrogen level at the outflow did not exceed $0.3 \mathrm{mg}$ TAN dm ${ }^{-1}$, and nitrite did not exceed $0.05 \mathrm{mg} \mathrm{NO}_{2}$ $\mathrm{dm}^{-1}$. During the experiments the water parameters were within optimum ranges for Atlantic sturgeon (Mohler 2003).

\section{Measurements and statistical analyses}

At the end of each experiment, 15 individuals were collected from each of the experimental groups, and body weight (to the nearest $0.001 \mathrm{~g}$ ) and total length (to the nearest $0.1 \mathrm{~cm}$ ) measurements were taken. The total fish biomass in each tank was determined. At the end of experiment II, the fish were sorted, and three size groups were created: slow, medium, and fast growth rates within body weight ranges, respectively, $\mathrm{S}<0.2 \mathrm{~g}$; M 0.2-0.3 g; F $>0.3$ g.
The data collected was used to calculate the following rearing parameters: specific growth rate SGR $\left(\% \mathrm{~d}^{-1}\right)=100 \times\left(\ln \mathrm{BW}_{2}-\ln \mathrm{BW}_{1}\right) \times \mathrm{t}^{-1} ;$ Fulton's condition coefficient $\mathrm{K}=100 \times \mathrm{BW}_{\mathrm{m}} \times \mathrm{Lt}^{-3}$; coefficient of body weight variation $\mathrm{CV}(\%)=100 \times \mathrm{SD} \times$ $\mathrm{BW}^{-1}$; feed conversion ratio $\mathrm{FCR}=\mathrm{TFC} \times(\mathrm{FB}-\mathrm{IB})^{-1}$; protein efficiency ratio $\mathrm{PER}=(\mathrm{FB}-\mathrm{IB}) \times \mathrm{TFP}^{-1}$; stock survival $\mathrm{P}(\%)=100\left(\mathrm{FN} \times \mathrm{IN}^{-1}\right)$; where: $\mathrm{BW}_{1}$ - initial body weight (g), BW 2 - final body weight (g), BW body weight $(\mathrm{g}), \mathrm{BW}_{\mathrm{m}}$ - mean body weight $(\mathrm{g}), \mathrm{t}-$ rearing time (days), Lt - total length $(\mathrm{cm}), \mathrm{SD}$-standard deviation, IB - initial fish biomass (g), FB - final fish biomass (g), IN - initial number of fish (indiv.), FN - final number of fish (indiv.), TFC - total feed consumption (g), TFP - total feed protein (g).

The results obtained in experiments I and II were analyzed separately. Statistical analysis was performed with Statistica 5.0 Pl (StatSoft Inc.). The homogeneity of variance was verified with Levene's test. The significance of differences among the mean values of rearing indexes in the analyzed groups was determined with one-way analysis of variance (ANOVA). If statistically significant differences were found, further analysis was conducted with Tukey's test at a level of significance of $\mathrm{P}<0.05$.

\section{Results}

\section{Experiment I}

The highest final body weight was obtained by the fish in group T9, while the lowest was in group T12 $(\mathrm{P}<0.05)$. The specific growth rate $(\mathrm{SGR})$ was also the highest in group T9 at $12.6\left(\% \mathrm{~d}^{-1}\right)(\mathrm{P}<0.05$; Table 1). The timing of first feeding with live feed was not found to impact fish condition, feed conversion ratio (FCR), or protein efficiency ratio (PER) (P > 0.05; Table 1). The fish in group T9 were characterized by the highest body weight variation, which was statistically significantly different from the other experimental groups $(\mathrm{P}<0.05$; Table 1$)$. Fish survival in all groups was similar at the end of the experiment (Table 1). 
Table 1

Selected rearing parameters of Atlantic sturgeon (A. oxyrinchus) larvae fed Artemia sp. nauplii on different days: 6 DPH (group T6), 9 DPH (group T9), 12 DPH (group T12) (mean values \pm SD; $\mathrm{N}=3$ )

\begin{tabular}{llll}
\hline \hline & Group & & \\
\cline { 2 - 3 } Parameter & T6 & T9 & T12 \\
\hline \hline Initial body weight (g) & $0.007 \pm 0.001$ & $0.007 \pm 0.001$ & $0.007 \pm 0.001$ \\
Final body weight (g) & $0.036 \pm 0.005^{\mathrm{ab}}$ & $0.044 \pm 0.003^{\mathrm{a}}$ & $0.030 \pm 0.006^{\mathrm{b}}$ \\
Specific growth rate SGR (\% d $\left.{ }^{-1}\right)$ & $11.0 \pm 1.1^{\mathrm{ab}}$ & $12.6 \pm 0.4^{\mathrm{a}}$ & $9.8 \pm 1.4^{\mathrm{b}}$ \\
Body weight coefficient of variation CV (\%) & $19.8 \pm 2.4^{\mathrm{a}}$ & $30.5 \pm 4.8^{\mathrm{b}}$ & $17.8 \pm 4.3^{\mathrm{a}}$ \\
Initial body length (cm) & $1.1 \pm 0.1$ & $1.1 \pm 0.1$ & $1.1 \pm 0.1$ \\
Final body length (cm) & $1.8 \pm 0.1$ & $2.0 \pm 0.1$ & $1.8 \pm 0.1$ \\
Condition coefficient K & $0.54 \pm 0.02$ & $0.56 \pm 0.05$ & $0.54 \pm 0.06$ \\
Protein efficiency ratio (PER) & $1.77 \pm 0.21$ & $2.10 \pm 1.45$ & $1.60 \pm 0.87$ \\
Feed conversion ratio (FCR) & $1.13 \pm 0.15$ & $1.40 \pm 1.13$ & $1.57 \pm 1.24$ \\
Survival (\%) & $74.6 \pm 2.8$ & $73.3 \pm 4.3$ & $63.7 \pm 35.3$ \\
\hline \hline
\end{tabular}

Groups with different letter indexes differ significantly statistically $(\mathrm{P}<0.05)$

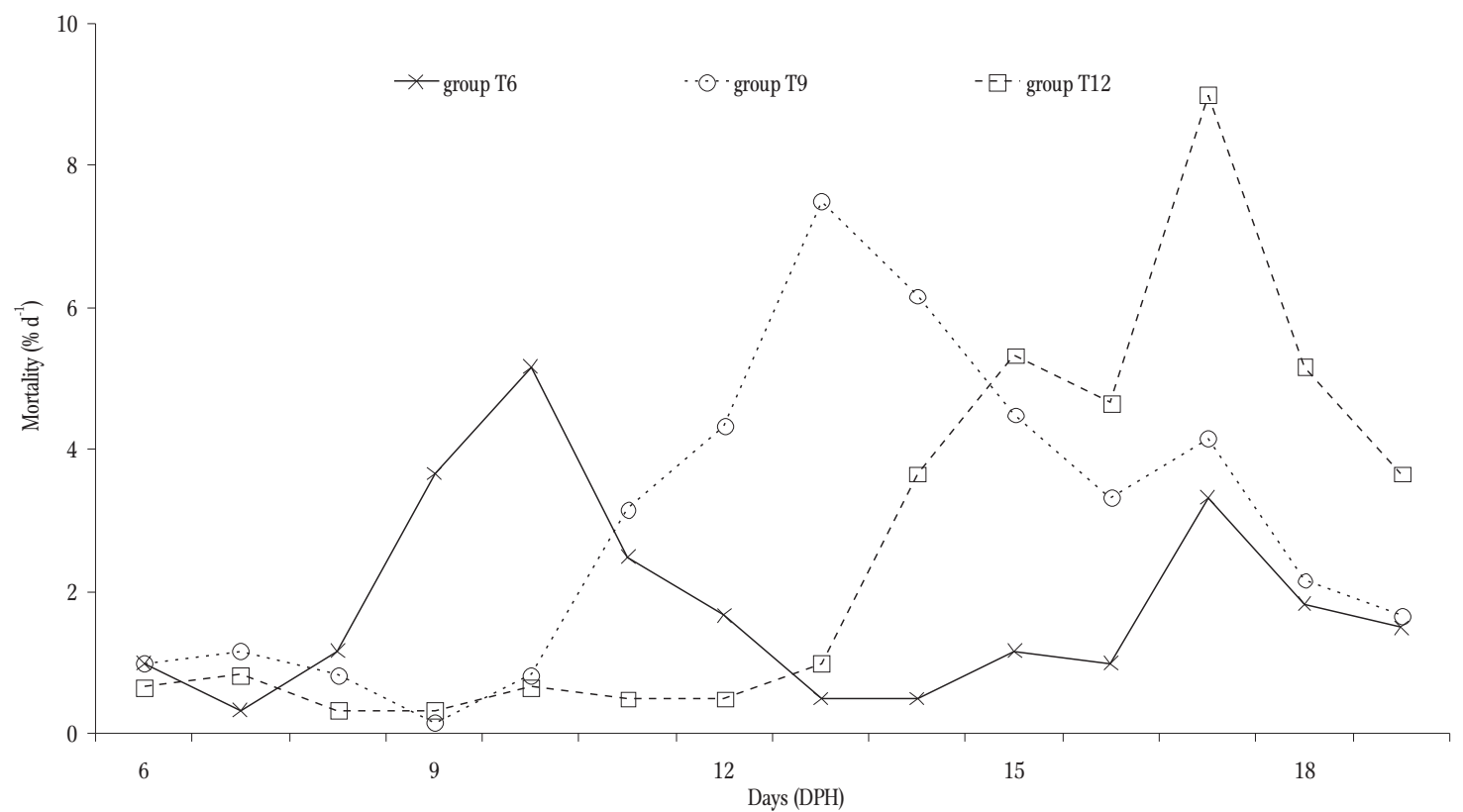

Figure 1. Course of losses during the rearing of Atlantic sturgeon (A. oxyrinchus) larvae fed Artemia sp. nauplii on different days: 6 DPH (group T6), 9 DPH (group T9), $12 \mathrm{DPH}$ (group T12) (mean values $\pm \mathrm{SD} ; \mathrm{N}=3$ ).

Larval mortality in all groups was related to the timing of first feeding, and the highest increase in losses was noted approximately four days after its initiation (Fig. 1). In groups T6 and T9, two periods of heightened mortality were recorded. The first was after food intake (10 DPH and $12 \mathrm{DPH}$, respectively). During this time, the weakest individuals that did not begin feeding and those with over-filled gastrointestinal tracts died. In group T6, dead fish included individuals that fed but in which melanin plugs had not yet been expelled (7-8 DPH). The second stage of heightened mortality was $17 \mathrm{DPH}$, when mainly weak and starving individuals died. On the same day, the highest losses occurred in group T12. 
Table 2

Selected rearing parameters of Atlantic sturgeon (A. oxyrinchus) larvae fed formulated feed on different days: 20 DPH (group F20), 25 DPH (group F25), 30 DPH (group F30) (mean values \pm SD; N = 3)

\begin{tabular}{llll}
\hline \hline & Group & & \\
\cline { 2 - 3 } Parameter & F20 & F25 & F30 \\
\hline \hline Initial body weight (g) & $0.048 \pm 0.001$ & $0.048 \pm 0.001$ & $0.048 \pm 0.001$ \\
Final body weight (g) & $0.44 \pm 0.05^{\mathrm{a}}$ & $0.40 \pm 0.02^{\mathrm{ab}}$ & $0.37 \pm 0.02^{\mathrm{b}}$ \\
Specific growth rate SGR (\% d ${ }^{-1}$ ) & $7.93 \pm 0.21^{\mathrm{a}}$ & $7.63+ \pm 0.21^{\mathrm{ab}}$ & $7.30 \pm 0.20^{\mathrm{b}}$ \\
Body weight coefficient of variation CV (\%) & $27.3 \pm 7.0$ & $34.7 \pm 6.3$ & $34.5 \pm 4.9$ \\
Initial body length (cm) & $1.9 \pm 0.1$ & $1.9 \pm 0.1$ & $1.9 \pm 0.1$ \\
Final body length (cm) & $4.8 \pm 0.3$ & $4.5 \pm 0.2$ & $4.3 \pm 0.2$ \\
Condition coefficient K & $0.40 \pm 0.02$ & $0.41 \pm 0.01$ & $0.42 \pm 0.01$ \\
Protein efficiency ratio (PER) & $2.63 \pm 0.27^{\mathrm{b}}$ & $2.93 \pm 0.16^{\mathrm{ab}}$ & $3.14 \pm 0.11^{\mathrm{a}}$ \\
Feed conversion ratio (FCR) & $0.62 \pm 0.06^{\mathrm{b}}$ & $0.55 \pm 0.03^{\mathrm{ab}}$ & $0.51 \pm 0.02^{\mathrm{a}}$ \\
Survival (\%) & $79.3 \pm 2.3$ & $76.6 \pm 1.5$ & $77.1 \pm 4.5$ \\
\hline \hline
\end{tabular}

Groups with different letter indexes differ significantly statistically $(\mathrm{P}<0.05)$

\section{Experiment II}

The varied timing of first feeding with formulated feed effected final fish body weight. The individuals in group F20 obtained the highest mean body weight, which was statistically significantly higher than that in group F30 ( $<$ 0.05; Table 2). The fish in group F20 also had a significantly higher specific growth rate (SGR) compared to those in group F30 ( $\mathrm{P}<0.05$; Table 2). The most advantageous feed conversion ratio (FCR) values were noted in group F30 at 0.51 $(\mathrm{P}<0.05$; Table 2). The fish from this group also had better protein efficiency ratios in comparison to the fish in group F20, and the difference between these groups was significant $(\mathrm{P}<0.05$; Table 2$)$. The timing of first feeding with formulated feed did not impact final fish body length, the condition coefficient (K), or the coefficient of body weight variation $(\mathrm{CV})(\mathrm{P}>$ 0.05; Table 2). At the conclusion of the experiment, the survival of larval Atlantic sturgeon was similar in all experimental groups (Table 2).

Increased losses in all analyzed groups were noted from $33 \mathrm{DPH}$, i.e., after the Artemia sp. nauplii ration was reduced. The highest losses were noted after live feed was totally excluded from the diets (44-45 DPH). The course of losses in the various groups differed. In groups F20 and F25, mortality was distributed over time, while in group F30 it proceeded more rapidly (Fig. 2). Smaller fish that did not feed and had clearly injured tails predominated. The share of such individuals at the end of the experiment in groups F20, F25, and F30 was 4.2, 3.8 and $2.3 \%$, respectively.

On the concluding day of the experiment the most individuals with fast growth rates were noted in group F20, and the least were in group F30. The share of such individuals in the overall number of sturgeon fry was $36.2 \%$ (group F20), 27.0\% (group F25), 21.8\% (group F30).

\section{Discussion}

The timing of first feeding is important for rearing strategies. If provided too soon, unconsumed feed can cause deteriorating environmental and sanitary conditions during rearing, while delaying first feeding can lead to a reduction in the efficiency the fish searching for and assimilating food, which result in reduced rates of growth and survival (Ghelichi et al. 2010). 


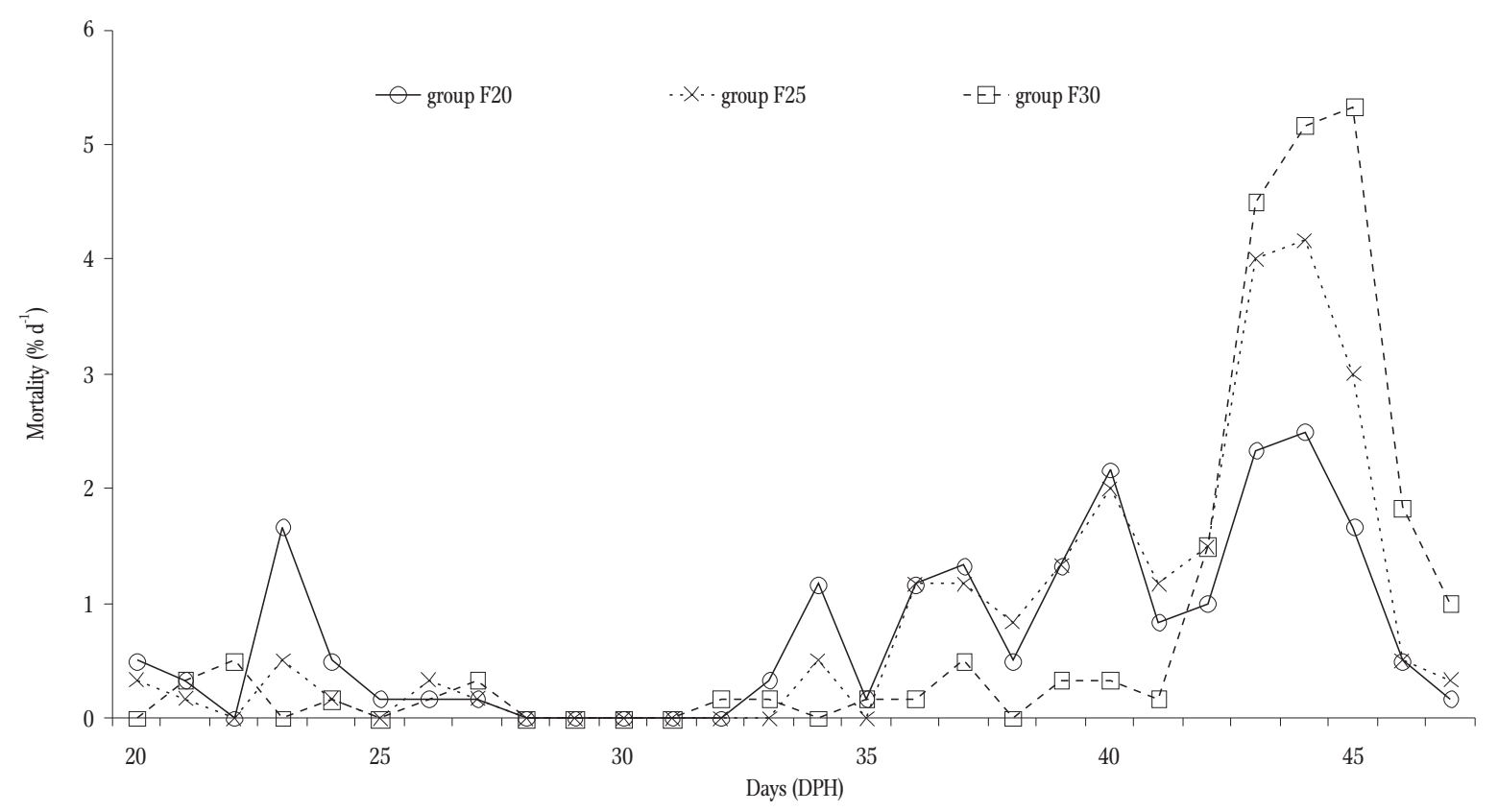

Figure 2. Course of losses during the rearing of Atlantic sturgeon (A. oxyrinchus) larvae fed formulated feed on different days: 20 DPH (group F20), 25 DPH (group F25), 30 DPH (group F30) (mean values \pm SD; $N=3$ ).

Atlantic sturgeon larvae exhibit behaviors that are typical for other sturgeon species (Gisbert and Williot 1997, Kynard et al. 2002a). Immediately after being placed in rearing tanks, they swim actively throughout the entire water column and then school, and from 6 DPH they disperse across the bottom surface of the tanks. This behavior appears just before the start of exogenous feeding (Kolman 2006, Szczepkowski et al. 2007). At this stage of rearing, the larvae expel their melanin plugs, which fill the spiral end of the gastrointestinal tract (Kolman et al. 2008). In sturgeons, inter alia the White sturgeon, Acipenser transmontanus Richardson, the assumption is that the beginning of exogenous feeding coincides with the expulsion of the melanin plug (Gawlicka et al. 1995), and Ostos-Garrido et al. (2009) also report that larval Adriatic sturgeon, Acipenser naccarii Bonaparte expelled melanin plugs after the first feeding. However, according to Dettlaff et al. (1993), the first feeding should be initiated when $2-3 \%$ of the larvae have expelled their melanin plugs. Ostaszewska et al. (2011) also followed this guideline to determine the timing of the first feeding of larval Atlantic sturgeon. When melanin plugs are expelled depends largely on water temperature: at water temperatures of $22^{\circ} \mathrm{C}$, this occurred as early as 6 DPH (Szczepkowski et al., 2007), while at water temperatures of $17-19^{\circ} \mathrm{C}$ it happened on 9-10 DPH (Kolman et al. 2008, Szczepkowska et al. 2010, Szczepkowski et al. 2010, Piotrowska et al. 2013). In our experiment, the first melanin plugs were expelled in group T6 the day after the first feeding. This could indicate that the introduction of food stimulates the larvae to shift from endogenous to exogenous feeding.

Chebanov and Galich (2011) report that in Huso huso (L.) and Huso dauricus (Georgi) if first feeding is initiated too soon the result can be larval death. This was also confirmed by our observations, because in the larval group in which first feeding was initiated the earliest we noted some dead individuals that had full digestive tracts and melanin plugs that had not been expelled. These individuals accounted for 3.3\% of all the dead fish in this group, while in the other groups such losses were not noted. In turn, Chai et al. (2011) suggest that feeding larval Chinese sturgeon, Acipenser sinensis Gray, during endogenous nutrition facilitated acquainting the fish with new flavors and aromas, which significantly increased their chances of survival. Thus, one can assume that the 
timing and method of first feeding initiation is specific to different species.

It should also be noted that the timing of first feeding should be correlated with the beginning of exogenous feeding in most of the larvae. Some authors contend that first feeding should happen when $30-50 \%$ of larvae have resorbed yolk sacs (Gawlicka et al. 2000). Chai et al. (2014) observed that among larval Chinese sturgeon, which received food immediately after endogenous feed reserves were depleted, only $7.7 \%$ had full digestive tracts. In contrast, in groups in which first feeding was initiated later, the number of foraging larvae increased to $73.3 \%$, which resulted in these larvae achieving greater weight gains and higher survival rates. According to these authors' research findings, first feeding is best initiated 2-3 days after the larvae begin exogenous feeding, because by then the efficiency of the digestive system and the ability to search for food have both improved. In our experiment we also observed that larvae fed with a three-day delay (9 DPH) obtained higher body weights.

In practice, however, determining exactly the timing of first feeding is difficult, because the period of yolk sac resorption varies widely in individual larvae, which is most probably related to the size of the larvae, and, thus, yolk sac size. Gisbert et al. (2000) reports that the larger the yolk sac is, the longer larvae use these reserves, which, in turn, can mean that the start of exogenous feeding extends over time. Kolman et al. (2008) report that Atlantic sturgeon larvae resorb yolk sacs in 8-12 days depending on water temperature. In our experiment, we also observed that larvae used endogenous reserves at different rates. A similar difficulty is posed by timing first feeding based on observations of melanin plug expulsion, because this process can take about 3-4 days (Chebanov and Galich 2011). It can also be assumed that the timing of first feeding on different days could affect the rate of yolk sac resorption stimulating larvae to shift more quickly to exogenous feeding (Chebanov and Galich 2011).

Fish mortality occurred mainly between 10 and $17 \mathrm{DPH}$, which was similar to that observed in previous Atlantic sturgeon rearing (Szczepkowska et al. 2009, Piotrowska et al. 2010). This course of mortality has also been observed in other sturgeon species (Gawlicka et al. 1995, Kynard et al. 2002a). It should also be noted that mortality concerned larvae that had not fed and those that had fed copiously. Gisbert and Williot (1997) report that $70-75 \%$ of dead Acipenser baerii Brandt larvae had food in their stomachs. Mortality in larvae with very full digestive tracts is characteristic for the Atlantic sturgeon and could stem from them being unable to digest the large quantities of Artemia sp. nauplii in their gastrointestinal tracts (Piotrowska et al. 2010). At this stage of development, most sturgeon already have established, functioning digestive systems (Gawlicka et al. 1995, Gisbert and Doroshov 2003), even if digestive enzyme activity is relatively low (Żółtkowska et al. 1999, Asgari et al. 2014). Additionally, food exposure time to the enzymes is very short because of the length of the larval intestinal tract, which is several times shorter than that in fry (Govoni 1986).

Equally important to the timing of first feeding is the possibility of using formulated feeds. The use of live feed in traditional sturgeon rearing is estimated to account for more than $50 \%$ of total costs (Salehi 2006), which is why replacing live feed with formulated feed can reduce costs significantly. Some sturgeon species, e.g., the Siberian sturgeon, can consume formulated feed immediately after endogenous feeding ends (Gisbert and Williot 1997, Napora-Rutkowski et al. 2009). In turn, Persian sturgeon, Acipenser persicus Borodin shifted from live to formulated feed between 19-24 DPH (Babaei et al. 2011). The Atlantic sturgeon is a species that has difficulty adapting to formulated feed. According to Mohler (2003), this species effectively transitioned to formulated feed after it had reached a body weight of $180 \mathrm{mg}$ and a body length of $34.5 \mathrm{~mm}$. In our experiment, we observed that the lowest body weight at which Atlantic sturgeon larvae shifted to formulated feed was $151 \mathrm{mg}$ at a body length of $33.1 \mathrm{~mm}$. Effective digestion of starter feeds in the initial period, however, requires active enzymes, and live feed is the source of these exogenous enzymes (Cahu and 
Zambonino-Infante 2001). Atlantic sturgeon digestive system cells and secretory glands are still forming in the third week after hatching, and some authors recommend the administration of a live feed from 10 to $30-35 \mathrm{DPH}\left(19^{\circ} \mathrm{C}\right)$ (Ostaszewska et al. 2011). In our experiment, live food was administered until $40 \mathrm{DPH}$, and formulated feed was introduced from 20 to $30 \mathrm{DPH}$. Larvae that received formulated feed the earliest adapted to it faster, which was indicated by the level of losses in the experimental groups after the elimination of live feed. Klassen and Peake (2008) observed that among larval lake sturgeon, Acipenser fulvescens Raf. there was a group of fish that did not adapt to the change of feed, and this led to mortality. Chebanov et al. (2011) state that the shift from one feed to another should be gradual and that it can last up to 14 days. Our study indicates that the longer period of supplying mixed feed had a positive effect on the growth of the fish, but it did not affect their survival.

In comparison to the growth of other sturgeon species, that of Atlantic sturgeon fry is slower (Szczepkowski et al. 2004). The SGR results obtained in the current study were similar to those of other authors (Mohler et al. 2000, Szczepkowska et al. 2010). Fish with different growth rates were observed in all the experimental groups, and especially after formulated feed was introduced. In the group fed formulated feed the earliest, the share of fast growing individuals was the highest (36.2\%), which indicates that the larvae adapted to formulated feed more quickly. Size differences, however, have a negative effect on fish rearing. According to observations by Kynard and Horgan (2002b) of larval Atlantic sturgeon and shortnose sturgeon, Acipenser brevirostrum Lesueur, larger individuals attacked smaller ones and assumed the most favorable positions with regard to feed availability. Larger individuals were also more mobile, thanks to which they were able to consume feed faster. In our experiment, the dead individuals from all experimental groups had injured tails, which indicated cannibalistic behavior in individuals that grew rapidly. The fastest growing individuals were noted in the group that received formulated feed the earliest, while the least were in the group in which formulated feed was introduced the last at 2.3-4.2\%, respectively. Gisbert et al. (2000) noted a similar level of losses during A. baerii rearing.

Fish size differences and the large number of individuals with slow growth rates influenced feed utilization efficiency. According to Kolman et al. (2008), compared to other sturgeon species, larval Atlantic sturgeon feed utilization efficiency is relatively low. Even after the fish shifted to formulated feed, the FCR value was 1.2-1.3. In our experiment, the FCR value range was $0.51-0.62$, which was much more favorable and comparable with the results obtained by Mohler et al. (2000).

The results of the present study indicated that the best strategy for rearing larval Atlantic sturgeon was to initiate first feeding with a delay so that the fish could acclimate to the new feed. The results obtained permit concluding that the optimum moment for first feeding with live feed was $9 \mathrm{DPH}$ and with formulated feed $20 \mathrm{DPH}$.

Acknowledgements. This study was conducted within the framework of statutory research project S-023 at the Inland Fisheries Institute in Olsztyn.

Author contributions. I.P. designed the research; I.P., B.SZ., M.K. and M.SZ. performed the research; I.P., M.K, M.SZ. analyzed the data; I.P., B.SZ., M.SZ. wrote the paper.

\section{References}

Asgari R., Rafiee G., Eagderi S., Shahrooz R., Poorbagher H., Adh N., Gisbert E. 2014 - Ontogeny of the digestive system in hatchery produced Beluga (Huso huso Linnaeus, 1758); a comparative study between Beluga and genus Acipenser - Aquacult. Nutr. 20: 595-608.

Bardi R.W., Chapman F.A., Barrows F.T. 1998 - Feeding trials with hatchery-produced Gulf of Mexico sturgeon larvae - Prog. Fish. Cult. 60: 25-31.

Babaei S.S., Kenari A.A, Nazari R., Gilbert E. 2011 - Developmental changes of digestive enzymes in Persian sturgeon (Acipenser persicus) during larval ontogeny Aquaculture 318: 138-144. 
Boucher M.A., McAdam S.O., Shrimpton J.M. 2014 - The effect of temperature and substrate on the growth, development and survival of larval white sturgeon Aquaculture 430: 139-148.

Bronzi P., Rosenthal H., Gessner J. 2011 - Global sturgeon aquaculture production: an overview - J. Appl. Ichthyol. 27: 169-175.

Cahu C., Zambonino-Infante J. 2001 - Substitution of live food by formulated diets in marine fish larvae Aquaculture 200: 161-180.

Chai Y., Xie C., Wei Q.W. 2011 - Yolk-sac absorption and point of no return in Chinese sturgeon Acipenser sinensis larvae - J. Appl. Ichthyol. 27: 687-689.

Chai Y., Tan F.X., Li L.X., Wei Q.W. 2014 - Effects of delayed initial feeding on growth and survival of Chinese sturgeon (Acipenser sinensis Gray, 1835) larvae - J. Appl. Ichthyol. 30: 1590-1595.

Chebanov M., Rosenthal H., Gessner J., Van Anrooy R., Doukakis P., Pourkazemi M., Williot P. 2011 - Sturgeon hatchery practices and management for release - Guidelines FAO Fisheries and Aquaculture Technical Paper No. 570, Ankara, FAO. 110 p.

Chebanov M.S., Galich E.V. 2011 - Sturgeon hatchery manual - FAO Fisheries and Aquaculture Technical Paper No. 558, Ankara, FAO, 303 p.

Dettlaff T.A., Ginsburg A.S., Schmalhausen O.I. 1993 - Sturgeon fishes. Developmental biology and aquaculture Springer-Verlag, Berlin, 300 p.

Gawlicka A., Teh S.J., Hung S.S.O., Hinton D.E., De la Noiiel J. 1995 - Histological and histochemical changes in the digestive tract of white sturgeon larvae during ontogeny Fish Physiol. Biochem. 14: 357-371.

Gawlicka A., Parent B., Horn M.H., Ross N., Opstad I., Torrissen O.J. 2000 - Activity of digestive enzymes in yolk-sac larvae of Atlantic halibut (Hippoglossus hippoglossus): indication of readiness for first feeding Aquaculture 184: 303-314.

Ghelichi A., Makhdoomi N., Jorjani S., Taheri A. 2010 Effect of water temperature on the timing of initial feeding of Persian sturgeon Acipenser persicus larvae - Int. Aquat. Res. 2: 113-119.

Gisbert E., Doroshov S.I. 2003 - Histology of the development digestive system and the effect of food deprivation in larval green sturgeon (Acipenser medirostris) - Aquat. Liv. Res. 16: 77-89.

Gisbert E., Ruban G.I. 2003 - Ontogenic behavior of Siberian sturgeon, Acipenser baeri : A synthesis between laboratory tests and field data - Environ. Biol. Fish. 67: 311-319.

Gisbert E., Williot P. 1997 - Larval behavior and effect of the timing of initial feeding on growth and survival of Siberian Sturgeon (Acipenser baeri) larvae under small scale hatchery production - Aquaculture 156: 63-76.
Gisbert E., Williot P., Castelló-Orvay F. 1999 - Behavioural modification in the early life stages of Siberian sturgeon (Acipenser baeri, Brandt) - J. Appl. Ichthyol. 15: 237-242.

Gisbert E., Williot P., Castelló-Orvay F. 2000 - Influence of egg size on growth and survival of early stages of Siberian sturgeon (Acipenser baeri) under small scale hatchery conditions - Aquaculture 183: 83-94.

Govoni J.J., Boehlert G.W., Watanabej Y. 1986 - The physiology of digestion in fish larvae -Environ. Biol. Fish. 16: 59-77.

Hardy R.S., Litvak M.K. 2004 - Effects of temperature on the early development, growth, and survival of shortnose sturgeon, Acipenser brevirostrum, and Atlantic sturgeon, Acipenser oxyrhynchus, yolk-sac larvae - Environ. Biol. Fish. 70: 145-154.

Hermanowicz W., Dojlido J., Dożański W., Kosiorowski B., Zerze J. 1999 - Physicochemical studies of water and sewage - Arkady, Warszawa: 71-91 (in Polish).

IUCN 2010 - IUCN red list of threatened species. Version 2017. 3. - Available at: http://www.iucnredlist.org (accessed on 09 January 2017).

Kamali A., Kordjazi Z., Nazary R. 2006 - The effect of the timing of initial feeding on growth and survival of ship sturgeon (Acipenser nudiventris) larvae: a small-scale hatchery study - J. Appl. Ichthyol. 22: 294-297.

Klassen C.N., Peake S.J. 2008 - Effect of diet switch timing and food source on survival and growth of lake sturgeonJ. Appl. Ichthyol. 24: 527-533.

Kolman R. 2006 - Sturgeon. Reading and Ongrowing. A Breeder's Manual. - Wyd. IRS, Olsztyn: 69-75 (in Polish).

Kolman R., Kapusta A., Szczepkowski M., Duda A., Bogacka-Kapusta E. 2008 - The Atlantic sturgeon, Acipenser oxyrhynchus oxyrhynchus Mitch. - Wyd. IRS, Olsztyn: 5-73 (in Polish).

Kolman R., Kapusta A., Duda A., Wiszniewski G. 2011 Review of the current status of the Atlantic sturgeon Acipenser oxyrinchus oxyrinchus Mitchill 1815, in Poland: Principles, previous experience, and results - J. Appl. Ichthyol. 27: 186-191.

Kynard B., Henyey E., Horgan M. 2002a - Ontogenetic behavior, migration, and social behavior of pallid sturgeon, Scaphirhynchus albus, and shovelnose sturgeon, $S$. platorynchus, with notes on the adaptive significance of body color - Environ. Biol. Fish. 63: 389-403.

Kynard B., Horgan M. 2002b - Ontogenetic behavior and migration of Atlantic sturgeon, Acipenser oxyrinchus oxyrinchus, and Shortnose sturgeon, A. brevirostrum, with notes of social behavior - Environ. Biol. Fish. 63:137-150.

Mohler J.W. 2003 - Culture manual for the Atlantic sturgeon Acipenser oxyrinchus oxyrinchus - U.S. Fish \& Wildlife Service, Hadley, Massachusetts: 1-66. 
Mohler J.W., Kim King M., Farrell P.R 2000 - Growth and survival of first-feeding and fingerling Atlantic Sturgeon under culture conditions - N. Am. J. Aquacult. 62: 174-183.

Napora-Rutkowski L., Kamaszewski M., Bielawski W., Ostaszewska T., Wegner A. 2009 - Effects of Starter Diets on Pancreatic Enzyme Activity in Juvenile Sterlet (Acipenser ruthenus) - Isr. J. Aquacult.-Bamid. 61: 143-150.

Ostaszewska T., Kolman R., Kamaszewski M., Wiszniewski G., Adamek D., Duda A. 2011 - Morphological changes in digestive tract of Atlantic sturgeon Acipenser oxyrinchus during organogenesis -Int. Aquat. Res. 3: 101-105.

Ostos-Garrido M.V., Llorente J.I., Camacho S., García-Gallego M., Sanz A., Domezain A., Carmena R. 2009 - Histological, histochemical and ultrastructural changes in the digestive tract of sturgeon Acipenser naccarii during early ontogeny - In: Biology, Conservation and Sustainable Development of Sturgeons. Fish \& Fisheries Series, vol 29 (Eds) R. Carmona, A. Domezain, M. García-Gallego, J.A. Hernando, F. Rodríguez, M. Ruiz-Rejón, Springer, Dordrecht: 121-154.

Piotrowska I., Szczepkowska B., Kozłowski M., Wunderlich K., Szczepkowski M. 2010 - Impact of live feed type on the results of rearing larval Atlantic sturgeon (Acipenser oxyrhynchus oxyrhynchus Mitchill) - Komun. Ryb. 2: 1-4 (in Polish).

Piotrowska I., Szczepkowska B., Kozłowski M., Wunderlich K., Szczepkowski M. 2013 - Results of the larviculture of Atlantic sturgeon (Acipenser oxyrinchus) fed different types of diets - Arch. Pol. Fish. 21: 53-61.

Salehi H. 2006 - A brief analysis on the economics of fingerling productionof sturgeons in Iran: a case study for the period 2002-2003 - J. Appl. Ichthyol. 22: 257-260.

Sanz A., Lorente J.I., Furné M., Ostos-Garrido M.V., Carmona R., Domezain A., Hidalgo M.C. 2011 - Digestive enzymes durning ontogeny of the sturgeon Acipenser naccarii: intestine and pancreas development - J.Appl. Ichthyol. 27: 1139-1146.

Szczepkowska B., Szczepkowski M., Kolman R. 2009 Impact of feeding on the culture of larval hybrid Siberian sturgeon (Acipenser baerii) with Russian sturgeon (Acipenser gueldenstaedtii) - In: Reproduction, culture, and prophylactics in salmonids and other fish species (Eds) Z. Zakęś, K. Demska-Zakęś, A. Kowalska, D. Ulikowski, Wyd.awnictwo IRS, Olsztyn: 301-306 (in Polish).

Szczepkowska B. Szczepkowski M. , Kolman R., Piotrowska I. 2010 - Comparing results of rearing Atlantic sturgeon (Acipenser oxyrinchus) imported to Poland as spawn or larvae. In: Reproduction, rearing, prophylactics of rare fish under protection and other species. (Eds) Z. Zakęś, K. Demska-Zakęś, A. Kowalska, Wydawnictwo IRS, Olsztyn: 151-158 (in Polish).

Szczepkowski M., Kolman R., Szczepkowska B. 2000 Postembryonic development survival and growth rate of siberian sturgeon (Acipenser baeri Brandt) larvae - Arch. Pol. Fish. 8: 193-204.

Szczepkowski M. , Kolman R., Szczepkowska B. 2004 - The use of different formulated diets in preliminary rearing of sturgeon larvae - In: Reproduction, culture, and prophylactics in sturgeon and other fish species (Eds) Z. Zakęś, R. Kolman, K. Demska-Zakęś, T. Krzywosz, Wydawnictwo IRS, Olsztyn: 63-68 (in Polish).

Szczepkowski M., Kolman R., Szczepkowska B. 2007 - Atlantic sturgeon, Acipenser oxyrhynchus oxyrhynchus Mitch. larviculture - Initial results and observations - In: Restoring the Atlantic Sturgeon (Ed.) R. Kolman, Wydawnictwo IRS, Olsztyn: 27-36 (in Polish).

Szczepkowski M., Szczepkowska B., Kolman R., Piotrowska I. 2010 - Using Artemia salina in a larviculture system for Atlantic sturgeon (Acipenser oxyrinchus) - Results and observations of larval sturgeon cultured in a semi-production scale - In: Reproduction, culture, and prophylactics for rare fish and those under conservation and other species (Eds) Z. Zakęś, K. Demska-Zakęś, A. Kowalska, Wydawnictwo IRS, Olsztyn: 143-149 (in Polish).

Szczepkowski M., Szczepkowska B, PiotrowskaI. 2011 Impact of higher stocking density of juvenile Atlantic sturgeon, Acipenser oxyrinchus Mitchill, on fish growth, oxygen consumption, and ammonia excretion - Arch. Pol. Fish.19: 59-67.

Żółtowska K., Kolman R., Łopieńska E., Kolman H. 1999 Activity of digestive enzymes in siberian sturgeon juveniles (Acipenser baeri Brandt) - a preliminary study Arch. Pol. Fish. 7: 201-211. 